\title{
Amphibian and reptile diversity in Mt. Kalatungan Range Natural Park, Philippines
}

\author{
Angela Grace Toledo-Bruno ${ }^{1}$, Daryl G. Macas' ${ }^{1}$ Dave P. Buenavista², Michael Arieh P. Medina ${ }^{1 *}$, \\ Ronald Regan C. Forten ${ }^{1}$
}

\author{
${ }^{1}$ Department of Environmental Science, College of Forestry and Environmental Science, Central Mindanao University, University \\ Town, Musuan, Bukidnon, Philippines 8710 \\ ${ }^{2}$ Department of Biology, College of Arts and Sciences, Central Mindanao University, University Town, Musuan, Bukidnon, Philippines \\ 8710 \\ *Corresponding author, E-mail: mapmedina@cmu.edu.ph
}

\begin{abstract}
Herpetofauna inventory was conducted in the montane forest of Mt. Kalatungan Range Natural Park. Sampling plots were established in the lower montane at 1200 to $1400 \mathrm{~m}$ above sea level and upper montane at 1400 to $1600 \mathrm{~m}$ above sea level. Using a combination of pitfall trap and visual encounter methods, a total of 202 individuals were recorded belonging to 15 species, nine families and 12 genera, six of which are Mindanao endemic species. Five species belong to the IUCN Red List, which includes Limnonectes magnus, Ansonia muelleri, Ansonia mcgregori, Philautus acutirostris and Rhacophorus bimaculatus. Richness and diversity indices were consistently higher in the upper montane than in the lower montane. Similarity index of the two sites was only $26 \%$, which implies that herpetofauna have specific habitat and food requirements for their survival. Threats in the area include habitat disturbance due to forest fire and conversion of forest to agriculture. These threats should be the focus of conservation efforts of local government units and the community to protect the habitat of these wildlife.
\end{abstract}

Key words: herpetofauna diversity, Mindanao, montane forest, pitfall trap.

Abbreviations: HL, head length; HW, head witdth; INWARD, Integrated Watershed Research and Development; masl, meters above sea level; SVL, snout to vent length; TL, tail length.

\section{Introduction}

The Philippines archipelago with more than 7000 islands, is one of the mega diverse countries but at the same time a global biodiversity hotspot (Myers et al. 2000). It is considered to be among the hottest of hotspots largely due to habitat alteration and destruction, overexploitation, pollution, introduction of invasive species as well as destructive anthropogenic activities (Brown et al., 2001; Mallari et al. 2001; McKinney 2002; Diesmos 2006). One of the severely threatened group of fauna are amhpibians and reptiles, collectively termed herpetofauna. As exothermic organisms, herpetofauna are sensitive to changes in the microclimate conditions, making them indicators of the quality of the environment. In fact, the study of Diesmos (2008) revealed that 48 of the 78 herpetofauna species in the Philippines are on the brink of extinction.

Due to the alarming threat to herpetofauna diversity, assessment is important because the Philippines is one of the known centers of herpetofaunal diversity in Southeast Asia (Diesmos et al. 2002). Thus, it is crucial to document the species in their remaining habitats, especially forest ecosystems in protected areas such as the montane forest of Mt. Kalatungan Range Natural Park in Bukidnon, Philippines. This is part of the Integrated Watershed Research and Development (INWARD) Phase 2 - Muleta watershed project under the PCAARRD-DOST funding. This study is confined within the study site of the INWARD project.

Generally, this study assesses the herpetofauna diversity in the INWARD project site within the Mt. Kalatungan Natural Park. Specifically, this study aimed to: (1) compare the biodiversity indices of herpetofauna between upper and lower montane forest of Mt. Kalatungan in Brgy. Portulin; (2) determine the local and IUCN conservation status of herpetofauna species observed; and (3) assess the threats of herpetofauna species in the area. The findings of this study are input into the over-all watershed management database and decision-making tools of the Muleta watershed.

\section{Materials and methods}

Two sampling sites were established within the natural forest of Mt. Kalatungan Range in Barangay Portulin, Pangantucan, Bukidnon. Portulin is geographically located $4^{\circ} 22^{\prime} 33.36^{\prime \prime} \mathrm{N}$ and $128^{\circ} 21^{\prime} 58.70^{\prime \prime} \mathrm{E}$, surrounded with 
rolling hills and mountains. The climate falls within type III, characterized as having a short dry season lasting only from 1 to 3 months. Highest amount of rainfall occurs on June while March is the driest month.

Primary data were obtained in the established sampling areas, i.e. the upper montane with an elevation of 1400 to $1600 \mathrm{~m}$ above sea level (masl) and lower montane ranging from 1200 to 1400 masl as shown in Fig. 1. The distance between upper and lower montane is approximately two to three kilometers. Delineation of upper and lower montane forest was based on vegetation types of the sampling areas. The characteristics of these montane forests are shown in Fig. 2. The upper montane traverses the Lumagouk River with vegetation dominated by Lithocarpus sp, Syzygium sp., Clethra canescens, Elaeocarpus calomala, Lithocarpus sulitii, Neolitsea vidalii, Adenandra apoensis, Macaranga dipterocarpifolia associated with rattan and ferns. On the other hand, Baguik-ikan River traverses in the lower montane forest were characterized by steep slope with agro-forestry type of vegetation such as red lauan (Shorea negrosensis), white lauan (Shorea contorta), guava (Psidium guajava), kalomata and coconut (Cocos nucifera) and mixture of other species such as cogon (Imperata cylindrica), tree ferns (Cyathea contaminans), ground ferns and wild sunflower (Tithonia sp.), bamboo (Bambusa sp.), makahiya (Mimosa pudica), badiang (Colocasia sp.) and coffee (Coffea arabica).

Sampling was done within the delineated sampling plot and its vicinity of the project INWARD-Muleta watershed. Fieldwork was conducted from May to June 2016. Prior to sampling, Bukidnon experienced a long period of drought due to El Niño. Opportunistic sampling was employed to collect data for reptiles by checking a variety of microhabitats, i.e. tree trunks, tree crevices, root tangles, fallen logs, leaf litters, beneath rocks and in water tributaries. Capture - mark - release technique was supplemented with visual observation and pitfall trap methods to gather data on the distribution of herpetofauna species. The pitfall trap method determined the species richness of herpetofauna in the upper montane forest by capture of amphibians like caecilians and ground dwelling frogs and toads. Pitfall traps were either covered or uncovered. The plywood cover was suspended above the opening of the trap to protect from rain and partly to attract reptiles and amphibians. On the other hand, traps next to logs were placed on the down-hill side of the $\log$ (Corn, Bury 2012). Empty cans were placed on dug holes. Ten traps per sampling site were regularly checked during nighttime and daytime. In addition, visual observation during late morning and early afternoon as well as nocturnal surveys were conducted to exhaust all means possible to capture reptile and amphibian species.

All collected specimens were photo-documented and identified. Three days sampling in the upper montane forest and three days in the lower montane forest were conducted for both diurnal and nocturnal reptile and amphibian species. Data gathered included morphometrics for species identification; species name and taxonomic classification; elevation; and the microhabitat, which were classified accordingly to: arboreal habitat (5 to $10 \mathrm{~m}$ from the ground), ground habitat (0 to $5 \mathrm{~m}$ from the ground), and aquatic ecosystem. Other observations were noted such as activities in the area and other forms of disturbances.

Amphibians and reptiles captured were identified using taxonomic guides of Nuñeza (2012) and Diesmos et al. (2015). Species captured were documented and morphological features were measured using digital vernier caliper viz., snout to vent length (SVL), head length (HL), head width (HW) and tail length (TL). Species were tagged using thread to indicate capture before release. Species were categorized using the IUCN (2015) to determine its conservation status. Biodiversity indices were computed complemented with descriptive analysis from interviews to compare herpetofauna in the lower and upper montane forests.

Biodiversity indices were used to analyze the data gathered. These indices included the frequency, relative

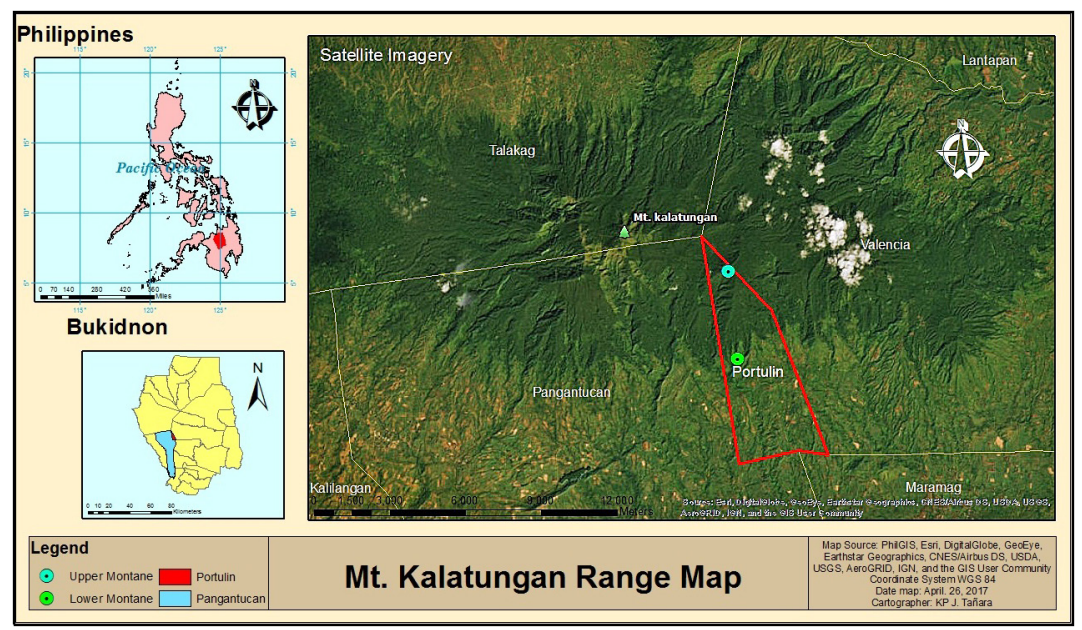

Fig. 1. Map of the study site. 
abundance, richness, diversity and dominance. The following biodivesity indices were used for data analysis (Magurran 1988; Iskandar, Kotanegara 1993).

Relative species abundance refers to how common or rare species is relative to others in a given location or community with the following formula.

Relative frequency $=$ total number of individuals of species / total number of individuals of all species $\times 100$. Menhinick's Index $D=s / \sqrt{ } N$,

where $s$ is the number of different species found, $N$ is the total number of individuals.

$$
\text { Shannon-Weiner Index } H=\sum_{i=1}^{s} p_{\mathrm{i}} \ln p_{\mathrm{i}} \text {, }
$$

where $p_{i}$ is the proportion of the $\mathrm{i}^{\text {th }}$ species, $\ln$ is the natural logarithm.

Shannon Evenness Index $J=H^{\prime} / H_{\max }$

where $H^{\prime}$ is Shannon index, $H_{\max }$ is the maximum diversity possible calculated as $\ln (s)$ or the natural logarithm of the total number of $s$ species.

Jaccard similarity index $\mathrm{SJ}=c / a+b+c$,

where $c$ is the number of species common to both areas $\mathrm{A}$ and $\mathrm{B} ; a$ is the number of species occurring in area A only; $b$ is the number of species occuring in area B only.

Purposive sampling was used to select ten respondents in the community of Barangay Portulin, Pangantucan, Bukidnon based on the established criteria such as knowledgeable on amphibians and reptiles and with at least ten years of residence in the area. Information gathered include local conservation status (abundance) and threats of reptiles and amphibians in the sites. The interviews used formulated questions prior to face-to-face interviews which were descriptive in nature. Questions revolved around community utilization, threats and conservation initiatives to protect the reptiles and amphibians. All responses were collected and collated for descriptive presentation of the data.

\section{Results and discussion}

\section{Occurrence of species in the sampling site}

A total of 15 species of reptiles and amphibians were recorded in the entire duration of the sampling. These species were verified from taxonomic guides and from biometrics taken from captured species. Habitat type where these species were captured were also noted. Photos of species are presented in Fig. 3. The following are the descriptions of species captured.

\section{Ansonia muelleri (Inger, 1954)}

The species has a synonym of Bufo muelleri (Boulenger, 1887) and reported to be found only in Mindanao and Dinagat Island, Philippines, hence referred as a Mindanao endemic (Warguez et al. 2013). It has green marks on the back side, two green bands in the forelimb and hind

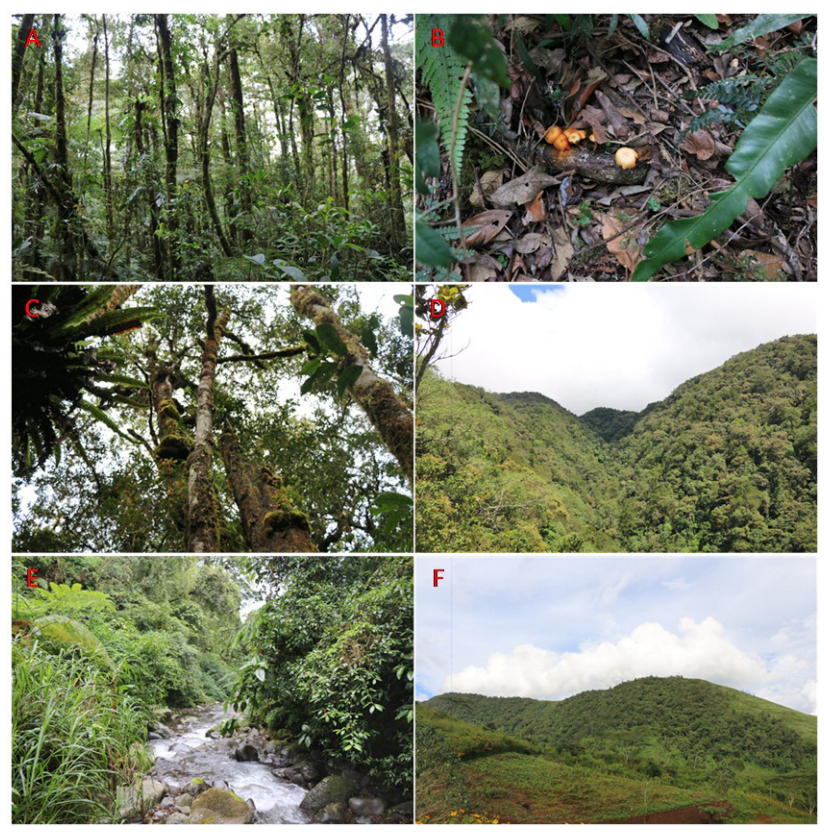

Fig. 2. Characteristics of sampling sites at the upper montane (A, $\mathrm{B}, \mathrm{C}$ and $\mathrm{D}$ ) and lower montane (E and F) forests.

limb with a greater degree of webbing in the toes. In Mt. Kalatungan, most individuals of this species were observed on rocks of Baguik-ikan River in the lower montane forest with an elevation 1200 to 1400 masl. Biometrics taken for this species showed an average SVL of $27.07 \mathrm{~mm}$; HL of $8.40 \mathrm{~mm}$; HW of $8.08 \mathrm{~mm}$.

\section{Ansonia mcgregori (Inger, 1960)}

The species is synonymous to Bufo mcgregori (Tylor, 1962) also known as Mcgregor's stream toad reported to be distributed in the Western Mindanao, particularly in Zamboanga province (Warguez et al. 2013). It was observed in Baguik-ikan river, both in upper and lower montane forest with an elevation of 1200 to 1600 masl. The species was found on rotten logs and rocks covered with mosses. The species has an average SVL of $25.22 \mathrm{~mm}$; HL of 7.38 $\mathrm{mm}$; HW of $7.97 \mathrm{~mm}$.

\section{Limnonectes magnus (Dubios, 1987)}

The species has synonyms of Rana magna (Stejneger, 1910); Rana magna (Boulenger, 1920); Ranamodesta magna (Smith, 1927); Rana macgrodon magna (Inger, 1954); Rana magna magna (Inger, 1958) and Rana (Euphlyctis) magna (Dubios, 1981). It is reported to be distributed in Mindanao and Basilan Island (Warguez et al. 2013). This species was found in the upper and lower montane forest on rocks along Baguik-ikan river, with an elevation of 1200 to 1400 masl. The species has an average SVL of $85.10 \mathrm{~mm}$; HL of $33.15 \mathrm{~mm}$; HW of $30.84 \mathrm{~mm}$.

\section{Limnonectes cf. ferneri}

The species is reported to be distributed in the western part 


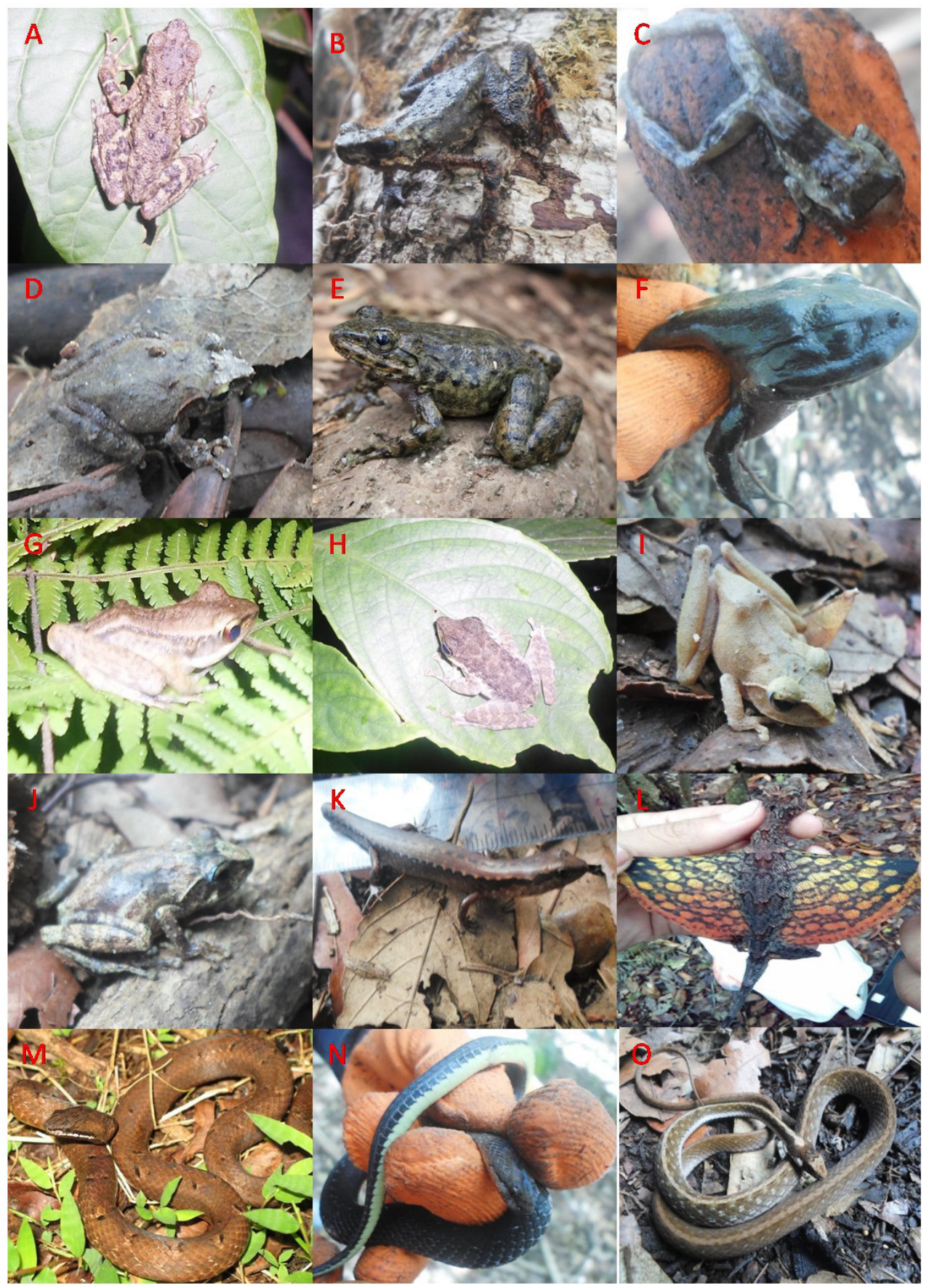

Fig. 3. Amphibians and reptiles present in Mt. Kalatungan Range National Park: Ansonia muelleri (A), Ansonia mcgregori (B), Philautus acutirostris (C), Rhacophorus bimaculatus(D), Limnonectes magnus (E), Limnonectes cf. ferneri (F), Hylarana grandocula (G), Staurois natator $(\mathrm{H})$, Philautus sp. 1 (I), Philautus sp. 2 (J), Pinoyscincus mindanensis (K), Draco volans (L), Psammodynastes pulverulentus (M), Cyclocorus lineatus $(\mathrm{N})$, Rhabdophis auriculata $(\mathrm{O})$.

of Mindanao. This species was observed on the rocks in the lower montane forest, with an elevation ranging 1200 to 1300 masl. It has an average SVL of $90.10 \mathrm{~mm}$; HL of 35.08 $\mathrm{mm}$; HW of $30.39 \mathrm{~mm}$.

\section{Rhacophorus bimaculatus (Peters, 1867)}

The species has synonyms of Leptomantis bimaculata (Peters, 1867); Leptomantis bimaculatus (Peters, 1867);
Philautus zamboangensis (Taylor, 1922); and Philautus bimaculatus (Peters, 1867). This species has been recorded in southern Luzon, Bohol, and Mindanao, Philippines (Diesmos et al. 2008). The species was observed on leaves of Crotalaria sp and other vegetation along Baguik-ikan River with an elevation of 1200 to 1400 masl. It has an average SVL of $14.10 \mathrm{~mm}$; HL of $5.95 \mathrm{~mm}$; HW of $4.89 \mathrm{~mm}$. 


\section{Staurois natator (Gunther, 1859)}

This species has synonyms of Staurois guttatus (Cope, 1865); Ixalus granulatus (Boettger, 1888); Rana natatrix (Boulenger, 1882); Rhacophorus granulosus (Ahl, 1927); and Rana guttatus (Smith, 1931). This species is distributed in Borneo, Bohol, Palawan, Busuanga, and Leyte and throughout Mindanao Island (Warguez et al. 2013). This species was observed on rocks and leaves along the Baguikikan River in the lower montane forest, with an elevation of 1200 to 1400 masl. It has an average SVL of $30.04 \mathrm{~mm}$; HL of $10.05 \mathrm{~mm}$; HW of $8.88 \mathrm{~mm}$.

\section{Hylarana grandocula (Inger and Tylor, 1996)}

The species has synonyms of Rana philipinensis (Taylor, 1920); and Rana yakani (Taylor, 1922). The species is reported to be found in the Bohol Island and in the mountains of Mindanao. It was observed on fern leaves in the lower montane forest along the Baguik-ikan river with an elevation of 1200 to 1300 masl. Average measurements: SVL of $50.01 \mathrm{~mm}$; HL of $22.39 \mathrm{~mm}$; HW of $19.88 \mathrm{~mm}$.

\section{Philautus acutirostris (Peters, 1867)}

The species has synonyms of Ixalus acutirostris (Peters, 1867); Philautus basilanensis (Taylor, 1922); and Philautus woodi (Stejneger 1905). It is only distributed in Basilan and Mindanao islands (Warguez et al. 2013). This species was observed on a leaf of an unkown small plant in the elevation of 1400 to 1600 masl in upper montane forest. The species has an average SVL of $22.05 \mathrm{~mm}$; HL of 9.08 $\mathrm{mm}$; HW of $8.38 \mathrm{~mm}$.

\section{Philautus sp. 1}

This species is locally called Balagdawan for the community of barangay Portulin, Pangantucan, Bukidnon. It was observed on a leaf $90 \mathrm{~cm}$ above the ground in the upper montane forest within 1400 to 1600 masl. It has an average SVL of $23.2 \mathrm{~mm}$, HL of $9.24 \mathrm{~mm}$ and HW of $8.64 \mathrm{~mm}$. The species is temporarily named Philautus sp. based on its morphometric size, microhabitat type and similarity on body form of Philautus acutirostris.

\section{Philautus sp. 2}

This species was observed on the leaf of small plant at about $40 \mathrm{~cm}$ above the ground in the upper montane forest with an elevation ranging from 1400 to 1600 masl where Philautus acutirostris was also found. This species has an average SVL of $19.63 \mathrm{~mm}$, HL of $8.89 \mathrm{~mm}$ and HW of $7.91 \mathrm{~mm}$. This species is temporarily named Philautus sp. 2 based on its morphometric size and microhabitat type, which is generally similar to genus Philautus.

\section{Pinoyscincus mindanensis (Taylor, 1915)}

This species has a synonym of Sphenomorphus mindanensis (Brown, Alcala 1980). It is distributed in Agusan, Leyte, Bohol and Mindanao (Uetz, Hallermann 2011). The species was observed on the forest floor and rotten logs with an elevation of 1300 to 1500 masl in the upper montane forest. The species has an average SVL of $50.28 \mathrm{~mm}$; HL of 11.41 $\mathrm{mm}$; HW of $7.89 \mathrm{~mm}$; TL of $20.08 \mathrm{~mm}$.

\section{Draco volans (Taylor, 1966)}

The species is commonly known as flying dragon and widely distributed in Southern India and Southeast Asia, including Borneo as well as Philippines (Van Arsdale 1999). The species was observed on a tree gliding to an adjacent tree. The species was found at elevation 1300 to 1500 masl in the upper montane forest. This species has an average SVL of $90.08 \mathrm{~mm}$; HL of $19.07 \mathrm{~mm}$; HW of $15.75 \mathrm{~mm}$; TL of $153.05 \mathrm{~mm}$.

\section{Psammodynastes pulverulentus (Boie, 1827)}

This species is commonly known as Mock Viper, Dusky Mock Viper, and Common Mock Viper. It is widely distributed in Thailand and Southeast Asia including Indonesia, Philippines, Vietnam, Nepal and Taiwan (Ecology Asia 2016). It was found on the twigs of a tree in the upper montane forest at elevation ranging from 1400 to1600 masl. Average body length: $390 \mathrm{~mm}$; HL of $20 \mathrm{~mm}$; HW of $12.02 \mathrm{~mm}$; TL of $104 \mathrm{~mm}$.

\section{Cyclocorus lineatus (Reinhardt, 1843)}

The species is endemic to the Philippines, where it has been recorded to be found in the islands of Lubang, Luzon, Mindoro, Polillo, Catanduanes, Marinduque, Guimaras, Cebu, Panay and Negros and found close to sea level around 1400 masl (IUCN, 2015). This species was found on a rotten log in the upper montane forest with an elevation ranging from 1400 to 1600 masl. Average body length of $89.02 \mathrm{~mm}$; HL of $19.11 \mathrm{~mm}$; HW of $11 \mathrm{~mm}$; TL of $29 \mathrm{~mm}$.

\section{Rhabdophis auriculata (Gunther, 1858)}

This species is endemic to the Philippine Islands where it is known from the islands of Basilan, Mindanao, specifically in the localities of Mount Hamiguitan; Surigao del Sur; Mount Hilong-Hilong; Mount Kampalili; Mount Malindang; Agusan Marsh; Mount Apo; the Diwata Range and the Malagos Watershed. The same species has been also sighted in Bohol, Leyte, Samar, Dinagat and Siargao. IUCN (2015) reported that this species is found between 75 (in Surigao Del Sur) to 2100 masl (in Mount Apo) This species was observed in upper and lower montane forest of Mt. Kalatungan at elevation 1200 to 1600 masl with an average body length of $394 \mathrm{~mm}$; HL of $14.66 \mathrm{~mm}$; HW of $8.10 \mathrm{~mm}$; TL of $145 \mathrm{~mm}$.

Species distribution and habitat types in the sampling site The 202 individuals captured in the two study sites belonged to 15 species, nine families and 12 genera (Table 1) of amphibians and reptiles, collectively known as herpetofauna. Most of these species were found on the 
Table 1. Distribution of amphibian and reptile species in the sampling sites. Ar, arboreal; Gr, ground; Aq, aquatic; Pt, pitfall trap; Ve, visual encounter

\begin{tabular}{|c|c|c|c|c|c|}
\hline Family & Species & Habitat type & $\begin{array}{l}\text { Sampling } \\
\text { technique }\end{array}$ & Frequency & $\begin{array}{c}\text { Relative } \\
\text { frequency (\%) }\end{array}$ \\
\hline \multicolumn{6}{|c|}{ Upper montane forest } \\
\hline \multicolumn{6}{|c|}{ Amphibia } \\
\hline \multirow[t]{2}{*}{ Bufonidae } & Ansonia muelleri & $\mathrm{Gr} / \mathrm{Aq}$ & Ve & 3 & 9.68 \\
\hline & Ansonia mcgregori & $\mathrm{Gr} / \mathrm{Aq}$ & $\mathrm{Pt} / \mathrm{Ve}$ & 1 & 3.23 \\
\hline Dicroglossidae & Limnonectes magnus & $\mathrm{Aq}$ & $\mathrm{Ve}$ & 3 & 9.68 \\
\hline \multirow[t]{3}{*}{ Rhacophoridae } & Philautus acutirostris & $\mathrm{Gr}$ & $\mathrm{Ve}$ & 1 & 3.23 \\
\hline & Philautus sp.1 & $\mathrm{Gr}$ & $\mathrm{Ve}$ & 1 & 3.23 \\
\hline & Philautus sp. 2 & $\mathrm{Gr}$ & $\mathrm{Ve}$ & 2 & 6.45 \\
\hline \multicolumn{6}{|c|}{ Reptilia } \\
\hline Agamidae & Draco volans & $\mathrm{Ar}$ & $\mathrm{Ve}$ & 1 & 3.23 \\
\hline Natricidae & Rhabdophis auriculata & $\mathrm{Gr}$ & $\mathrm{Ve}$ & 2 & 6.45 \\
\hline Scincidae & Pinoyscincus mindanensis & $\mathrm{Gr}$ & $\mathrm{Pt} / \mathrm{Ve}$ & 13 & 41.94 \\
\hline \multirow[t]{2}{*}{ Colubridae } & Psammodynastes pulverulentus & Ar & $\mathrm{Ve}$ & 3 & 9.68 \\
\hline & Cyclocorus lineatus & $\mathrm{Gr}$ & $\mathrm{Ve}$ & 1 & 3.23 \\
\hline Total: & 11 & & & 31 & 100 \\
\hline \multicolumn{6}{|c|}{ Lower montane forest } \\
\hline \multicolumn{6}{|c|}{ Amphibia } \\
\hline \multirow[t]{2}{*}{ Bufonidae } & Ansonia muelleri & $\mathrm{Gr} / \mathrm{Aq}$ & $\mathrm{Ve}$ & 30 & 17.54 \\
\hline & Ansonia mcgregori & $\mathrm{Gr} / \mathrm{Aq}$ & $\mathrm{Ve}$ & 24 & 14.04 \\
\hline \multirow[t]{2}{*}{ Dicroglossidae } & Limnonectes magnus & $\mathrm{Aq}$ & $\mathrm{Ve}$ & 52 & 30.41 \\
\hline & Limnonectes cf.ferneri & $\mathrm{Gr}$ & $\mathrm{Ve}$ & 21 & 12.28 \\
\hline Rhacophoridae & Rhacophorus bimaculatus & $\mathrm{Gr}$ & $\mathrm{Ve}$ & 2 & 1.17 \\
\hline \multirow[t]{2}{*}{ Ranidae } & Hylarana grandocula & $\mathrm{Gr} / \mathrm{Aq}$ & $\mathrm{Ve}$ & 7 & 4.09 \\
\hline & Staurois natator & $\mathrm{Gr} / \mathrm{Aq}$ & $\mathrm{Ve}$ & 32 & 18.71 \\
\hline \multicolumn{6}{|c|}{ Reptilia } \\
\hline Natricidae & Rhabdophis auriculata & $\mathrm{Gr}$ & $\mathrm{Ve}$ & 3 & 1.75 \\
\hline Total: & 8 & & & 171 & 100 \\
\hline
\end{tabular}

ground through visual encounter. Of the 15 species captured, 13 species inhabit both ground and aquatic microhabitat type while two species are arboreal. Species that inhabit ground and aquatic ecosystems indicate considerable thermal and hydrologic condition requirements, along with good water quality and watershed condition (Warguez et al. 2013). As observed, Baguik-ikan River is transparent with temperatures ranging from 17 to $19^{\circ} \mathrm{C}$.

Two species of anurans were undetermined, possibly belonging to genus Philautus. Six Mindanao endemic species of herpetofauna were recorded, which include Ansonia muelleri, Ansonia mcgregori, Philautus acutirostris, Limnonectes cf. ferneri, Pinoyscincus mindanensis, and Cyclocorus lineatus. Four species recorded in this study are widely distributed in the Philippines such as Hylarana grandocula, Staurois natator, Rhabdophis auriculata, and Rhacophorus bimaculatus while the rest are widespread or non-endemic such as Draco volans, Psammodynastes pulverulentus and Limnonectes magnus.

Amphibians and reptiles are exothermic organisms, which are dependent on the weather condition such as moisture and temperature. The weather was generally rainy and cloudy during sampling on the first week of May but there was no rain in the past weeks prior to sampling due to El Niño. This explains the lower number of ground, aquatic and arboreal amphibians observed during the entire sampling period.

A total of 11 species were observed in the upper montane and eight species in the lower montane forest. Four species were common to both sites viz., Ansonia muelleri, Ansonia cf. mcgregori, Limnonectes magnus and Rhabdophis auriculata. Seven species were observed in the upper montane forest, which include Philautus acutirostris, Philautus sp. 1, Philautus sp. 2, Draco volans, Pinoyscincus mindanensis, Psammodynastes pulverulentus, and Cyclocorus lineatus. The species observed at the lower montane forest were Rhacophorus bimaculatus, Limnonectes cf. ferneri, Hylarana grandocula and Staurois natator. This implies that species found in the two sampling sites may have different microhabitats and food requirements.

Pinoyscincus mindanensis has higher relative abundance in the upper montane forest where they were observed on fallen and rotten logs that are the habitat and food requirements of this species. On the other hand, 
Limnonectes magnus was observed to have higher relative abundance in lower montane forest due to the presence of the flowing Baguik-ikan River, which is suitable for habitat of this species. Three species (Philautus sp. 1, Philautus acutirostris, and Cyclocorus lineatus) had the lowest relative abundance in the upper montane forest, since the river in this portion was relatively dry due to the occurrence of El Niño in the past months prior to sampling.

Data from this study revealed a higher species richness in the upper montane compared to the lower montane forest. Similarly, the study of Arances, et al. (2006) showed a higher species richness of anurans in the upper montane compared to lower montane forest. This may be due to the greater heterogeneity of vegetation present in forested habitats that provide amphibians the needed microenvironmental requirements for their survival (Arances, et al., 2006). In addition, the Baguik-ikan River in the upper montane forest was not totally dry. This explains why there is higher relative abundance of species, particulary the anurans, which favour wetlands, as essential breeding habitat. The results of this study is in contrast to the study of Warguez, et al. (2013), in which the lower montane was observed to have low species richness of reptiles and amphibians due to sloping terrain. In this study, the lower montane forest is agro-forest type, parts of which were burned due to long dry spell brought about by El Niño. This is the reason why species richness was low in the lower montane forest.

\section{Herpetofauna diversity indices}

Diversity indices revealed that upper montane forest has higher diversity compared to the lower montane forest (Table 2). In addition, upper montane forest has higher species richness but low evenness value as compared to lower montane forest. The observed high species richness, particularly of anurans, is due to the vegetation type since they preferably inhabit intact forest rather than agro-forest area of the lower montane (Arances et al. 2006). Amphibian and reptile species are sensitive to habitat destruction and preferably inhabit undisturbed vegetation such as forested areas. Consequently, the lower montane forest in this study site has low species diversity due to disturbances along the sampling site such as camp trails, land conversion from forest to agriculture and forest fire. Pond and other temporary wetlands may influence the loss and increased isolation of important habitat types resulting from agriculture (Meyer et al. 1998). The occurrence of El Niño also accounted for the low diversity in the lower montane forest.

Data of this study also revealed that species richness of reptile was observed to be low both in the upper and lower montane forests due to high elevation. According to Alcala (1976), the majority of reptiles occur at lowlands with maximum elevation of 1200 masl or less while only few occur at high elevation. Note that the study sites have elevation ranging from 1200 to 1600 masl. The upper and lower montane forests have a similarity index of only $26 \%$, which implies that amphibians and reptiles have specific habitat and food requirements for their survival. Thus, the findings of this study revealed that the type of habitat, elevation, land conversion and the occurrence of El Niño influenced the diversity of amphibians and reptiles.

\section{Conservation status of herpetofauna}

Conservation status of amphibians and reptiles was assessed using the IUCN 2015 Red List. Five of the 15 species are considered threatened, as presented in Table 3. It is alarming to note that these species were observed in the lower montane forest, which is prone to disturbances such as forest fire and conversion of forest into agriculture. However, local conservation status revealed that most of the species captured were commonly seen in forest within the Mt. Kalatungan Range National Park, as per accounts of respondents of Barangay Portulin. In contrast, Philautus sp. 1, Draco volans and Cyclocorus lineatus were rarely observed.

\section{Community management practices for the conservation of herpetofauna}

The high relative abundance of anurans "provides food and indicate permanent reservoir from precipitation" (Jofre et al. 2010) since these species prefer wet habitats. In addition, amphibians and reptiles are considered indicators of environmental health since they "exploit a wide range of microhabitat and occupies wide range of tropic niches, from small invertebrate feeders through large mammal predators" (Klemens, Thorbjarnarson 1995). All these indicate the ecological importance of amphibians and reptiles that need to be protected and conserved. Despite the role of amphibians and reptiles in the ecosystems, they are subjected to threats from both anthropogenic or natural causes.

Interviews indicated that farming is the dominant source of income of the respondents, thus the demand of land for agriculture will continually threaten the survival

Table 2. Diversity indices of herpetofauna in the two sampling sites

$\begin{array}{lccc}\text { Diversity indice } & \text { Upper montane } & \text { Lower montane } & \text { Upper and lower montane } \\ \text { Menhinick's Index } & 1.98 & 0.61 & 1.06 \\ \text { Shannon-Weiner Diversity index } & 1.94 & 1.73 & 2.04 \\ \text { Shannon Evenness Index } & 0.81 & 0.83 & 0.75 \\ \text { Jaccard Similarity Index } & & 26 \% & \end{array}$


Table 3. Conservation status of herpetofauna

\begin{tabular}{llll}
\hline Scientific name & Local name & Local conservation & Conservation status (IUCN 2015) \\
\hline Ansonia muelleri & Antig & Common & Vulnerable \\
\hline Ansonia mcgregori & Antig & Common & Vulnerable \\
\hline Philautus acutirostris & Ut-ut & Common & Vulnerable \\
Rhacophorus bimaculatus & Baki & Common & Vulnerable \\
\hline Limnonectes magnus & Bak-bak & Common & Near threatened \\
Philautus sp. 1 & Balagdawan & Uncommon & Not evaluated \\
\hline Philautus sp. 2 & - & Common & Not evaluated \\
Limnonectes cf. ferneri & Baki & Common & Not evaluated \\
\hline Psammodynastes pulverulentus & Baligkangay & Common & Not evaluated \\
\hline Pinoyscincus mindanensis & Kalunog & Common & Not evaluated \\
\hline Draco volans & Tambukaka & Uncommon & Not evaluated \\
Cyclocorus lineatus & Handalukay & Uncommon & Not evaluated \\
Hylarana grandocula & Talagdaw & Common & Least concern \\
Staurois natator & Talagdaw & Common & Least concern \\
\hline Rhabdophis auriculata & Bitin & Common & Least concern
\end{tabular}

of amphibians and reptiles. In addition, the lower montane forest is adjacent to agricultural land and patches of grassland, which is vulnerable to forest fire and farming. In fact, a nearby farm was burned due to long dry spell of El Niño. Aside from conversion of the natural habitat, there are people hunting frogs and tadpoles locally, called bitabita, for food. Sixty percent of respondents admitted that some amphibian and reptile species are hunted for food and medicine. Hunting uses the electric current locally termed panguryente, which can kill the eggs and tadpoles in the Baguik-ikan River. Some amphibians and reptiles are also prey to larger animals. Aside from food and medicine, all respondents considered amphibians and reptiles as predators of pests in their farms.

The disturbance of habitat, predation and unregulated hunting are threats to some amphibians and reptiles that inhabit the forest of Mt. Kalatungan Range National Park. However, the local people have already organized the Bantay Lasang (Forest Guard) Programme, which was initiated by the Department of Environment and Natural Resources (DENR) and the local government of Barangay Portulin. Local forest guards are responsible in the implementation of the protection and conservation programs in Mt. Kalatungan (Table 4).

The community for its part also prohibited hunting of wildlife in the protected area, specifically in the upper montane forest. According to respondents interviewed, anybody caught will be penalized through payment of 500 pesos and one pig. Cutting of trees in the area, which leads to habitat destruction for wildlife, is also prohibited. Respondends narrated that cutting is only allowed for domestic purposes but planting of five trees is imposed by the Tribal Council prior to cutting a tree. In addition, the local government of Pangantucan and the DENR have initiated programs and projects in protecting the forest, such as conducting seminars on the value of forest, advocating the no cutting of trees and practicing reforestation in the area. However, lower montane forest has remarkable destruction of habitat due to camp trails, forest fires and land conversion to agricultural.

\section{Conclusions}

A total of 15 amphibians and reptiles were recorded in the lower montane and upper montane forest of Mt. Kalatungan Range National Park, Barangay Portulin, Pangantucan, Bukidnon. The study is, however, limited to the project INWARD-Muleta watershed biodiversity plot. Of the 15 species recorded, six are Mindanao endemic while four species are widely distributed in the Philippines. Species diversity is relatively higher in the upper montane forest as compared to the lower montane. The type of habitat, elevation, land conversion and the occurrence of El Niño influenced the diversity of herpetofuana in the

Table 4. Community conservation activities for herpetofauna based on interviews

\begin{tabular}{|c|c|}
\hline Parameter & Activity \\
\hline \multirow{2}{*}{$\begin{array}{l}\text { Implemented rules } \\
\text { and regulations }\end{array}$} & Hunting is regulated \\
\hline & Herps for consumption only \\
\hline \multirow{5}{*}{$\begin{array}{l}\text { Government-initiated } \\
\text { programs and } \\
\text { projects }\end{array}$} & Program on forest conservation \\
\hline & Seminar on wildlife and forest \\
\hline & protection \\
\hline & Bantay Lasang Program \\
\hline & Reforestation \\
\hline \multirow{3}{*}{$\begin{array}{l}\text { Measures to enhance } \\
\text { environmental } \\
\text { protection }\end{array}$} & $\begin{array}{l}\text { Community to regulate hunting } \\
\text { activities }\end{array}$ \\
\hline & $\begin{array}{l}\text { Imposed penalties to those who violate } \\
\text { the law }\end{array}$ \\
\hline & No kaingin (burning) \\
\hline
\end{tabular}


sampling site. Five species are categorized as threatened based on the IUCN (2015) Red List, i.e. one species is near threatened and four species are vulnerable. These species were recorded in the lower montane, which are prone to habitat disturbance. There is therefore a need for a joint and intensified effort of the community, local government and the national government, such as the DENR, to sustain their wildlife protection and conservation programmes.

\section{Acknowledgements}

This study is part of the INWARD Project, with Dr. Rex Victor O. Cruz as the Project Leader and Dr. George R. Puno and Dr. Rico A. Marin as Project Staff. We would like to gratefully acknowledge DOST-PCAARRD for the funding of the project and the support of the DENR, Mt. Kalatungan Range Natural Park PAMB, the Tribal Council and the community of Barangay Portulin in Pangantucan, Bukidnon. Data collection and safety of the team were assured because of the assistance of the local forest guards of Barangay Portulin.

\section{References}

Alcala A.C. 1976. Philippine Land Vertebrates: Field Biology. A College Texbook. New Day Publishers, Philippines, 167 p.

Arances J.B., Amoroso V.B., Nuneza O.M., Kessler P.J.A. 2006. Participatory Biodiversity Assessment in Malindang Range, Philippines. The Mt. Malindang Experience. Southeast Asian Regional Center for Graduate Study and Research in Agriculture (SEARCA) Biodiversity Research Programme (BRP) for Development in Mindanao: Focus on Mt. Malindang and Environs, $271 \mathrm{p}$.

Brown W.C., Alcala A.C. 1980. Philippine lizards of the family Scincidae. Silliman University Nat.Sci. Monogr. Ser. 2, Siliman University, Philippines, 264 p.

Brown R, Diesmos A., Alcala A.C. 2001. The state of Philippine herpetology and the challenges for the new decade. Siliman J. 42: 18-87.

Cao M.A.C. 2007. Diversity of anurans along elevational bands of Mt. Hilong Hilong, Diwata Range, Agusan Del Norte. Undergraduate thesis. Central Mindanao University, Bukidnon.

Corn P.S. Bury R.B.. 2012. Sampling Methods for Terrestrial Amphibians and Reptiles. General 'Technical Report PNWGTR-256. USDA Forest Service Pacific Northwest Research Station Portland, Oregon. 34 p.

Diesmos A. 2008. Ecology and diversity of herpetofaunal communities in fragmented lowland rainforests in the Philippines. A Dissertation. National University of Singapore. Singapore.

Diesmos A, Brown R., Alcala A., Sison R., Afuang L., Gee G. 2002. Amphibians and Reptiles. Philippine biodiversity conservation priorities. A second liberation of the national biodiversity strategy and action plan. Department of Environment and Natural Resources - Protected Areas and Wildlife Bureau (DENR- PAWD), Philippines, $26 \mathrm{p}$.

Diesmos A.C., Alcala A., Brown R., Afuang L.E. and Gee G. 2008. Rhacophorus bimaculatus. The IUCN Red List of Threatened Species 2008: e.T58980A11853445.http://dx.doi.org/10.2305/
IUCN.UK.2008.RLTS.T58980A11853445.en

Diesmos A.C., Diesmos M.L., Brown R.M. 2006. Status and distribution of alien invasive frogs in the Philippines. J. Environ. Sci. Manage. 9: 41-53.

Diesmos A.C., Watters J.L., Huron N.A., Davis D.R., Alcala A.C., Crombie R.I., Afuang L.E., Gee-Das G., Sison R.V., Sanguila M.B., Penrod M.L., Labonte M.J., Davey C.S., Leone E.A., Diesmos M.L., Sy E.Y., Welton L.J., Brown R.M. Siler C.D. 2015. Amphibians of the Philippines, Part I: Checklist of the Species. Series 4, Vol. 62, Part 3, No. 20: 457-539

Ecology Asia. 2015. Snakes of Southeast Asia. "Common Mock Viper". Retrieved from www.ecologyasia.com/verts/snakes/ common-mock-viper.htm on January 22, 2016.

Inger, R.F. 1954. Systematics and zoogeography of Philippine amphibia. Fieldiana Zool. 33: 182-531.

International Union for Conservation of Nature. 2015. The IUCN Red List Categories and Criteria version3.1. Retrieved from http://www.iucnredlist.org/static/categories_criteria_3_1. on May 25, 2016.

Iskandar J., Kotanegara R. 1993. Methodology for Biodiversity Research. In: Pei S., Sajise P.E. (eds) Regional Study of Biodiversity: Concepts, Framework, and Methods. Proceedings of the Southeast Asian Universities Agroecosystem Network (SUAN) and Program in Environment (ENV). East-West Center Workshop. Yunnan University Press.

Jofre M., Cid F., Caviedes-Vidal E. 2010. Spatial and temporal patterns of richness and abundance in athe anurans assemblage of an artificial water reservoir from the semi arid region of Argentina. Amphibia-Reptilia 31: 533-540.

Klemens M., Thorbjarnarson J. 1995. Reptiles as a food resource. Biodiv. Conserv. 4: 281-298.

Magurran A.E. 1988. Ecological Diveristy and its Measurement. Croom Helm Ltd. New South Wales.

Mallari N.A., Tabaranza B.R., Crosby M.J. 2001. Key Conservation Sites in the Philippines. A Haribon Foundation and Birdlife International Directory of Important Bird Areas. Bookmark, Inc. Makati City, Philippines. 485 p.

McKinney M.L. 2002. Urbanization, biodiversity and conservation. BioScience 52: 883-890.

Meyer A.H., Schmidt B.R., Grossenbacher K. 1998. Analysis of three amphibian populations with quarter- century long timeseries. Proc. Royal Soc. London 265:523-528.

Myers N., Mittermeier R.A., Mittermeier C.G., Da Fonseca G.A.B., Kent J.. 2000. Biodiversity Hotspots for Conservation Priorities. Oxford University, UK. Conservation International, USA. Centre for Applied Biodiversity Science, Conservation International, UK.

Nuńeza O.M. 2012. Photographic Guide to Amphibians and Reptiles of Mindanao, Philippines. Mindanao State University - Iligan Institute of Technology (MSU-IIT). Philippines. 72 p.

Uetz P., Hallerman J. 2012. Pinoyscincus mindanensis. The Reptile Data Base. Reptile-database.org. Retrieved from http//www. reptiledatabase.org on June 25, 2016

Van Arsdale M. 1999. Draco volans. (on-line), Animal Diversity Web. Retrieved from http://animaldiversity.org/accounts/ Draco_volans/ on October 15, 2016

Warguez D.A., Mondejar E.P. Demayo C.G. 2013. Frogs and their microhabitat preferences in the agricultural and secondary forest areas in the vicinity of Mt. Kalatungan Mountain, Bukidnon, Philippines. Int. Res. J. Biol. Sci. 2: 51-63. 